\title{
Mengabadikan estetika Fotografi dalam promosi pariwisata kolonial di Hindia-Belanda
}

\author{
ACHMAD SUNJAYADI
}

\begin{abstract}
ABSTR ACT
When the first technology of photography came to the Netherlands-Indies in the nineteenth century, it was only used for government purposes and was not yet meant for public consumption. On the other hand, the rise of colonial tourism in the Netherlands-Indies in the early twentieth century required a medium for promotion. Photographs were the right choice because, as the saying goes, pictures could tell more than words. Photographs for colonial tourism promotions were produced in various forms such as postcards, illustrations in magazines and guide books, and were published by the colonial government as well as by private publishers. This article discusses the role of photography in colonial tourism in the Netherlands-Indies and its influence in the process to 'find Indonesia'. The sources used are taken from published postcard collections, magazines, guide books, and also published government archives.
\end{abstract}

KEYWORDS

Fotografi, promosi, pariwisata kolonial, Hindia-Belanda.

\section{FOTOGR AFI SEBAGAI CATATAN SEJARAH}

Mendengar kata catatan biasanya kita akan mengacu pada tulisan. Sementara itu foto-foto cenderung hanya menjadi ilustrasi, pelengkap data-data sejarah. Hal itu mungkin ada benarnya juga karena kebanyakan orang hanya memaknai foto sebagai hasil pose yang enak dipandang. Di sini peran juru foto sangatlah besar. Dengan kata lain sehelai foto itu dapat saja penuh rekayasa.

Terlepas dari semua itu fotografi dan pariwisata merupakan dua hal yang tak dapat dipisahkan. Sebagai sarana promosi, foto-foto yang indah menjadi

ACHMAD SUNJAYADI adalah pengajar Program Studi Belanda dan anggota Departemen Sejarah, Fakultas Ilmu Pengetahuan Budaya, Universitas Indonesia. Pernah mengikuti kuliah di Dutch Studies, Leiden University, Belanda (2000-2001). Menyelesaikan pendidikan Magister Humaniora (S2), Fakultas Ilmu Pengetahuan Budaya, Universitas Indonesia pada tahun 2006 dengan tesis "Perhimpunan Turisme Batavia (1908-1942): Awal Turisme Modern di Jawa". E-mail: achmad.sunjayadi@ui.edu. Website: http://www.sunjayadi.com. 
daya tarik tersendiri dan juga diharapkan mampu menarik para wisatawan untuk datang dan menikmati objek yang telah dipersiapkan. Sehingga fotofoto yang 'direkayasa' itu mutlak diperlukan.

Dalam kurun waktu hampir lebih seabad, sejarah fotografi dan pariwisata di Indonesia menjadi suatu hal yang menarik untuk didiskusikan. Alasannya, secara estetika dan diskursus foto-foto promosi pariwisata mengenai Indonesia selama satu abad itu hampir tidak ada perubahan. Foto-foto yang ditampilkan dan digunakan hampir sama atau bahkan sama dengan di masa-masa awal fotografi digunakan sebagai bagian dari promosi pariwisata di awal abad kedua puluh.

Tulisan ini akan mendiskusikan peranan fotografi dalam promosi pariwisata masa kolonial di Hindia-Belanda serta pengaruhnya terhadap proses 'menemukan Indonesia' bangsa Indonesia melalui para founding fathers.

Beberapa pertanyaan yang diajukan adalah bagaimana peranan fotografi dalam promosi pariwisata kolonial di Hindia-Belanda, foto-foto apa yang disajikan, apa pengaruhnya pada masa itu dan sesudahnya. Sumber-sumber yang digunakan adalah sumber resmi tercetak, sumber sekunder serta sumber primer yang yang telah dibukukan (koleksi kartu pos).

\section{MENGABADIKAN REALITAS MELALUI LUKISAN}

Setelah kekuasaan VOC berakhir maka secara resmi Hindia-Belanda merupakan daerah koloni kerajaan Belanda terhitung 1 Januari 1800. Sejak saat itu pula kerajaan Belanda berhak mencampuri urusan pemerintahan di Hindia-Belanda serta para penduduknya (Termorshuizen 1993: 9). Segala hal diatur dan dibuat peraturannya (besluit), misalnya mereka yang hendak bepergian ke daerah lain harus meminta izin pada penguasa setempat. Bagi yang melanggar harus menghadapi sanksi, dalam bentuk hukuman denda maupun kurungan. ${ }^{1}$

Sementara itu muncul pula minat dan rasa ingin tahu terhadap masyarakat di Hindia-Belanda, baik dari segi kebudayaan maupun masyarakatnya. Minat dan rasa ingin tahu itu muncul terutama di masa pemerintahan Inggris tahun 1811-1816 di bawah kekuasaan Gubernur Jenderal T.S. Raffles. Bahkan Raffles secara khusus menuliskan hal tersebut dalam buku The history of Java (1817) yang berisi sejarah dan kebudayaan Jawa.

Upaya itu dilanjutkan oleh penggantinya, Gubernur Jenderal G.A.G.Ph. Baron van der Capellen yang secara khusus mempelajari daerah pedalaman di Hindia-Belanda, terutama di Jawa. Yang menarik perhatian adalah

$1 \quad$ Misalnya aturan pas (passenstelsel) bagi Vreemde Oosterlingen (orang Timur Asing) yang dikeluarkan oleh Gubernur Jenderal G.A.G.Ph. Baron van der Capellen tanggal 9 Januari 1821 berkenaan dengan Staatsblad No. 6. Isi sebenarnya aturan itu adalah wilayah keresidenan Priangan tertutup bagi semua orang Eropa dan Tionghoa kecuali mereka yang telah mendapatkan izin dari residen Priangan. Lihat pula izin memasuki wilayah HindiaBelanda bagi orang Eropa dan sederajat dalam Koninklijk Besluit No. 1 tanggal 15 September 1871, Indische Staatsblad 1872 No. 38 yang kemudian diubah dalam Indische Staatsblad 1881 No. 226, 1890 No. 186. Lalu aturan Toelatingskaart (kartu izin) bagi para pendatang untuk memasuki wilayah binnenlanden (pedalaman) di Jawa. Lihat pengalaman seorang pelancong Amerika Eliza R. Scidmore dalam Java: the garden of the East (1984: 39-40). 
laporan dari perjalanan dan ekspedisi baik yang singkat maupun lama pada tahun 1820-an di pulau itu dimuat dalam media cetak di Hindia-Belanda. Media cetak tersebut merupakan sumber penting bagi pengetahuan tentang kepulauan Hindia Belanda (Termorshuizen 1993: 10).

Media cetak pada masa itu merupakan milik pemerintah, seperti De Bataviasche Koloniale Courant, koran pemerintah yang didirikan oleh Gubernur Jenderal H.W. Daendels pada tahun 1810. Lalu di bawah kekuasaan Raffles didirikan De Java Gouvernement Gazette. Sedangkan media cetak milik swasta baru muncul di pertengahan abad kesembilan belas. ${ }^{2}$

Selain berfungsi sebagai koran pemerintah Hindia-Belanda yang berisi laporan resmi pemerintah serta berita-berita dari Eropa yang terkadang sudah tidak baru lagi, mingguan De Java Gouvernement Gazette ini sebenarnya ingin mencakup hal yang lebih luas. Oleh karena itu, di samping memuat memuat karya-karya sastra, redaktur dari mingguan tersebut meminta pada pembacanya untuk mengirimkan tulisan mengenai Hindia. Tetapi tampaknya himbauan redaktur mingguan itu tidak berhasil karena mingguan tersebut hanya sedikit memberikan informasi mengenai Hindia-Belanda.

Di bulan Agustus 1816 Inggris menyerahkan kekuasaannya pada Belanda. Pada tahun 1816 wilayah Hindia-Belanda hanya terdiri dari Jawa, kepulauan Maluku serta beberapa pos di Sumatera dan Borneo. Di samping itu terdapat beberapa klaim yang didasarkan pada kontrak-kontrak dari masa VOC. Pada bulan Agustus 1816 terbit De Bataviasche Courant yang menjadi koran resmi ketiga pemerintah. Pada tahun 1828 di masa Gubernur Jenderal Leonard Du Bus de Gisignies, koran itu berubah nama menjadi De Javasche Courant yang bertahan hingga pendudukan Jepang di Hindia tahun 1942 (Surjomihardjo dkk. 2002: 26).

Pemerintahan pada masa ini tampaknya telah belajar dari pengalaman pemerintah sebelumnya. Artikel yang dimuat dalam mingguan pemerintah tidak lagi hanya memuat laporan resmi pemerintah dan berita 'kadaluwarsa' dari Eropa. Mereka berupaya memuat reisverhalen (cerita-cerita perjalanan) terutama yang dapat memberikan informasi mengenai daerah koloni.

Ketika Belanda mengambil alih pemerintahan dari tangan Inggris ada kebutuhan mengenai informasi daerah koloni tersebut. Oleh karena itu, raja Willem I menganggapnya sebagai masalah serius dan ia mengirimkan para ahli/sarjana serta juru gambar ke Hindia untuk dapat menggambarkan situasi sebenarnya, seperti penulis sejarah, ahli ilmu alam, dan ilmu bumi. Merekalah yang menjadi sumber untuk cerita-cerita perjalanan tersebut (Van Goor 2000: 213).

Cerita-cerita perjalanan yang dimuat di koran pemerintah itu berisi gambaran tentang pemandangan, flora, dan fauna di wilayah yang didatangi, pengamatan tentang kebiasaan dan budaya masyarakat setempat dan catatan sewaktu mereka mendaki gunung-gunung yang tinggi (Termorshuizen 1993: 13).

Cerita-cerita perjalanan yang dimuat dalam koran milik pemerintah di Hindia (satu-satunya) pada tahun 1820-1830 dapat dikatakan sebagai sebagian

$2 \quad$ Lihat kajian Termorshuizen (2001) mengenai media cetak di Hindia-Belanda mulai dari surat kabar pertama dari zaman VOC hingga sekitar tahun 1905. 
sumber penting tentang pengetahuan sejarah, geografi, etnologi, dan ilmu hayat di kepulauan Hindia. Cerita-cerita perjalanan itu tidak hanya memuat banyak informasi mengenai keadaan daerah yang belum atau hampir tidak pernah dijelajahi. Cerita-cerita itu juga tak hanya berisi informasi tentang orang-orang maupun budaya daerah tersebut tetapi juga menceritakan bagaimana para penduduk pribumi pada masa itu dilihat dan menyambut para penjelajah Eropa (Europese reizigers). Sehingga bagi banyak orang Eropa, koran merupakan sumber pengetahuan mereka tentang penduduk pribumi Hindia (Termorshuizen 1993: 18).

Perhatian pada fase awal dari 'penemuan' kepulauan Hindia di tahun 1820 -an adalah terhadap pulau Jawa. Kemudian lebih spesifik lagi adalah daerah terdekat dari pusat pemerintahan di Batavia dan Buitenzorg yang terletak di Jawa Barat yang juga merupakan daerah yang sering dikunjungi (Termorshuizen 1993: 19).

Sementara itu bagi para utusan pemerintah yang tidak dapat melukis, disertakan juga ahli gambar atau pelukis seperti C.W.M. van de Velde dan A.A.J. Payen karena pada masa itu teknik fotografi belum dikenal. Karyakarya para juru gambar ini kebanyakan merupakan gambar pemandangan indah yang ternyata membantu untuk mengetahui situasi pada masa itu. Meskipun demikian dalam menilai gambar atau lukisan tersebut kita harus kritis karena mungkin saja gambar-gambar itu telah mereka tambah atau mungkin ada bagian yang tidak mereka gambar. Namun, setidak-tidaknya gambaran umum mengenai situasi pada masa itu, seperti pemandangan alam, sarana transportasi (jalan, gerobak, kuda), pakaian penduduk yang dikenakan, kebiasaan, kegiatan serta bentuk fisik rumah, secara umum cukup memberikan penjelasan kepada kita.

Setelah diperkenalkannya teknik litografi di Belanda sekitar tahun 1830-an, terbit buku-buku yang dihiasi dengan ilustrasi. Kelak, pada paruh kedua abad kesembilan belas, mulailah para seniman Belanda mengadakan perjalanan ke Hindia-Belanda. Kali ini tanpa perintah khusus atau tujuan ilmu pengetahuan. Memang pada masa ini Hindia-Belanda tidak lagi dianggap negeri antah berantah.

\section{PARA TUKANG POTRET PELOPOR}

Menurut catatan sejarah, 19 Agustus 1839 dianggap sebagai tanggal resmi penemuan fotografi. Adalah Louis J.M. Daguerre (1787-1851), seorang Prancis yang pada tanggal itu mengumumkan hasil eksperimen-eksperimennya. Sejak itu fotografi cepat menarik perhatian secara luas karena dengan memanfaatkan pengaruh sinar, memungkinkan membuat gambar yang tampak seperti keadaan sebenarnya. Sehingga manusia tidak lagi tergantung pada juru gambar, pelukis atau pemahat.

Namun, citra yang dihasilkan Daguerre adalah citra positif sehingga menjadi satu-satunya hasil rekaman. Satu hal yang bertentangan dengan industri dan produksi masal. Persoalan ini berakhir setelah seorang bangsawan dan ilmuwan Inggris, William Henry Fox Talbot (1800-1877) menemukan 
negatif dan mencetaknya di atas kertas.

Di Hindia-Belanda, foto-foto pertama atas pesanan Ministerie van Koloniën (Kementerian Urusan Negeri Jajahan) dibuat oleh dokter Jurrian Munnich (1817-1865), pejabat dinas kesehatan pada tahun 1842. Ia ditugaskan untuk melakukan perjalanan ke wilayah Jawa Tengah dan membuat catatan serta foto-foto pemandangan alam dan tanaman. Munnich ketika itu menggunakan daugerreotype, teknik hasil temuan Daugerre dengan mencetak foto di atas lembaran tembaga yang dilapisi dengan perak yang telah diiodinisasi. Namun, dari 64 gambar hasilnya sangat mengecewakan. Kegagalannya lebih bersifat teknis dan kelembaban udara tropis yang luput dari perhitungannya. Munnich sendiri melanjutkan pekerjaan sebagai pejabat dinas kesehatan di Semarang dan pada tahun 1842 ia mengirim laporannya Verslag der Photographische Proefnemingen op Java pada pemerintah Hindia-Belanda (Faber et al. 1988: 16).

Oleh karena hasil yang mengecewakan itu, kementerian melimpahkan pekerjaan itu pada Adolph Schaefer yang berasal dari Dresden. Ia mengusulkan pada pemerintah Hindia-Belanda untuk mengerjakan proyek foto dengan imbalan perjalanan gratis ke Batavia dan gaji selama sebulan. Pekerjaan pertama yang harus dilakukan adalah mengambil gambar patung-patung koleksi Het Bataviaasch Genootschap van Kunsten en Wetenschappen. Lalu ia berangkat ke Borobudur untuk memotret relief-relief di sana (Faber et al. 1988: 16). Pada masa ini foto-foto yang diambil adalah kebanyakan peninggalan kuno HinduBuddha seperti patung dan relief.

Pada tahun 1850-an, fotografi mengalami perkembangan cepat dengan dikenalnya prosede kolodion. Prosede itu memungkinkan untuk membuat beberapa afdruk (cetakan) dari satu negatif kaca. Pada masa itu sudah ada beberapa juru potret profesional yang bekerja berpindah-pindah di HindiaBelanda. Mereka mendirikan studio di kota besar di salah satu hotel atau rumah kenalan dan memasang iklan di koran setempat serta membuat potret dari setiap orang yang mau mengeluarkan uang untuk itu. Sesudah beberapa minggu atau beberapa bulan mereka melanjutkan perjalanan ke kota lain.

Di antara mereka itu terdapat dua orang juru potret muda berkebangsaan Inggris, yaitu Walter Bentley Woodbury dan James Page yang tiba di Batavia pada tanggal 18 Mei 1857. Mereka membuka studio pertama mereka di rumah seorang nyonya berkebangsaan Skotlandia yang sekarang kira-kira berada di bagian selatan Medan Merdeka. ${ }^{3}$

Beberapa tahun kemudian Isidore van Kinsbergen membangun studio foto di Batavia. Sekitar tahun 1870-an sejumlah fotografer Jerman dan Belanda mulai menyebar di Batavia, antara lain firma Petz \& Co., dan C. Krüger dan

\footnotetext{
Lihat brosur pameran foto Woodbury \& Page di Erasmus Huis Jakarta (18 Januari 24 Februari 1995) tulisan G.J. Knaap Woodbury \& Page fotografen in Indonesië, 1857-1908. Untuk hasil karya lengkap mereka lihat S. Wachlin, Woodbury \& Page: photographers Java (1994). Walter Bentley Woodbury (1834-1885), yang berkebangsaan Inggris, kemudian mengembangkan teknik foto 'Woodbury type', yang ia patenkan di London. Metode hasil penemuannya ini mungkin sangat penting pada saat itu, mengingat iklim di wilayah Hindia-Belanda memang kadang merepotkan proses penyinaran.
} 
A. Wüllisch. Sementara itu di kota besar lainnya didirikan pula studio foto, seperti J.B. Jasper, C.C.F. Perret dan H. Salzwedel di Surabaya dan S.W. Camerik dan R. Schütz \& Co. di Semarang (Faber et al. 1988: 54). Demikian pula kota-kota lainnya seperti Buitenzorg, Cirebon, Surakarta, Bandung, Magelang, dan Malang. Bahkan studio-studio foto tersebut terdapat pula di kota-kota di luar Jawa, seperti Kotaraja, Binjai, Medan, Brastagi, Gorontalo, dan Makassar (Faber et al. 1988: 179-192).

Para 'tukang potret' tersebut mengandalkan para individu yang ingin diabadikan gambarnya. Ternyata itu menjadi sumber pemasukan utama mereka. Para juru potret itu juga menerapkan gaya berpose yang berlaku di Eropa. Selain di studio, mereka juga dapat bekerja di lokasi-lokasi yang diinginkan para pelanggan. Tentunya tidak sembarang orang yang mampu membayar biaya 'pengabadian' gambar mereka.

Selain menerima pesanan foto dari individu tertentu, para juru potret itu juga menerima pekerjaan membuat cartes-de-visites (semacam kartu pos). Biasanya berupa seri gambar-gambar penduduk pribumi, adat istiadat, dan kebiasaan setempat. Kartu-kartu itu dilekatkan pada karton tebal berukuran sekitar $6 \times 9 \mathrm{~cm}$. Di bagian depan atau belakang dicantumkan nama firma dengan rangkaian huruf-huruf indah. Kartu ini juga berfungsi sebagai semacam reklame dan juga sebagai kartu pos yang dikirim ke 'kampung halaman' di Eropa. Secara tidak langsung kartu yang dikirim itu mempromosikan situasi di Hindia-Belanda.

Bentuk produk lain yang juga populer pada masa itu adalah kabinetfoto yang berukuran sekitar $11 \times 16 \mathrm{~cm}$. Produk ini sangat populer di kalangan orang Eropa (baca: Belanda) dan pribumi yang berada. Biasanya berupa foto keluarga, foto pernikahan, atau acara-acara khusus. Selain berfoto bersama, orang Eropa pada khususnya sangat senang berpose di depan rumah mereka, di taman atau sewaktu bertamasya, pacuan kuda, main tenis, berburu, di atas bendi, di atas kuda, dan semua hal yang berhubungan dengan kehidupan mereka di Hindia-Belanda. Hasil potret itu dipajang di ruang tamu di rumah mereka atau dikirim ke keluarga mereka di Belanda. Biasanya, kepulangan sebuah keluarga untuk selamanya ke Belanda diakhiri dengan foto bersama untuk kenang-kenangan (Bonnef dan Grant 1994: 57).

Baik orang Eropa maupun elite pribumi rupanya sangat senang difoto di studio yang lengkap dengan latar belakang artistik. Hal ini yang juga disukai para juru foto karena mereka dapat berkreasi dengan bebas. Latar belakang yang bervariasi dapat menjadi pilihan para pelanggan. Biasanya perabotan atau kelengkapan yang dipergunakan adalah meja, kursi, aneka karpet, batu karang buatan dari kertas, pagar kayu, tanaman, bunga, ranting-ranting kering bahkan buku-buku yang dapat dijadikan hiasan supaya tampak 'intelek'. Para pelanggan pun dapat menggunakan layar putih polos bila mereka menginginkan. Kemungkinan besar perabotan dan kelengkapan itu diadaptasi dari dunia teater.

Hal yang tidak kalah menarik lainnya adalah bagaimana mereka bergaya di depan kamera. Seperti potret-potret hasil bidikan firma Woodbury \& Page yang menghasilkan seri berbagai pengrajin dan pedagang. Pada tahun 1865, 
di studio mereka di Batavia, mereka mengambil potret prajurit Lombok. Dua prajurit Lombok yang berpakaian perang itu berpose saling berhadapan di depan layar polos lengkap dengan senjata. Mereka memandang ke arah lensa kamera dengan tatapan mata tajam penuh kebanggaan dan rasa percaya diri. Sementara pada potret yang lain, dua prajurit berdiri bersisian memegang senjata. Pandangan tajam mereka tidak ke arah lensa tetapi ke arah sudut kiri atas.

Salah satu nama juru potret lain yang terkenal adalah K. Cephas yang memiliki studio di Yogyakarta. Ia adalah orang indo dan merupakan juru potret istana. Biasanya ia menggunakan layar yang dilukis sebagai latar belakang. Karya-karya Cephas menampilkan kehidupan budaya bangsawan Jawa. Selain menggunakan layar yang dilukis, perlengkapan studio yang biasa ia gunakan adalah karpet dan meja kecil berkaki satu, tempat helm militer atau buku. Seperti potret Susuhunan Paku Buwono IX dari Surakarta yang berpose berdiri dengan pakaian militer ala Eropa. Ia mengenakan ikat kepala kain. Tangan kanannya memegang pedang dan tangan kirinya bertumpu pada sebuah buku yang terletak di meja kecil berkaki satu bersisian dengan helm militer. ${ }^{4}$

\section{MODEL TELANJANG}

Selain mengambil objek orang Eropa dan elite pribumi serta berbagai profesi penduduk, berbagai suku bangsa di Hindia-Belanda juga menjadi objek para juru potret komersial. Hal ini sejalan dengan trend orientalisme di Eropa di masa itu. Gambar-gambar berbagai suku bangsa yang eksotis itu menjadi gambar yang paling disukai terutama gambar telanjang perempuan pribumi. Bahkan gambar telanjang perempuan pribumi ini pada tahun 1887 dijadikan salah satu sarana propaganda, penarik minat para pemuda di Belanda untuk mendaftarkan diri menjadi prajurit cadangan di Hindia-Belanda. Tentu saja gambar-gambar itu mendapat sambutan antusias, termasuk salah seorang pemuda, Alexander Cohen (1864-1961).

Namun, ternyata apa yang diungkapkan dengan gambar-gambar itu tidak seindah surga dunia yang ditawarkan. Gambar-gambar perempuan pribumi telanjang itu hanya rekayasa para juru potret. Seperti yang diungkapkan oleh Cohen yang merasa tertipu dengan janji surga pemerintah Belanda. Cohen kelak menjadi seorang prajurit pemberontak dan sempat ditahan dalam waktu yang lama di penjara militer di Hindia. Komentar-komentar tajamnya melalui surat bersambung dimuat di Groninger Weekblad edisi bulan Juni hingga Agustus 1887 (Spoor 1980: 59-60). ${ }^{5}$

Menurut Cohen, potret-potret perempuan pribumi separuh telanjang atau telanjang itu dibuat di studio dengan mengambil model para prostitusi. Mereka berpose dengan gaya yang menantang dan vulgar. Mereka berbaring atau

Untuk karya-karya Cephas, lihat Knaap, Cephas Yogyakarta (1999).

Namun, ada pula seorang prajurit yang mengatakan sebaliknya, seperti dalam brievenverhaal (surat cerita) yang dimuat Bendera Wolanda edisi 1910-1912 setelah diedit H.C.C. Clockener Brousson, lihat terjemahan Sunjayadi dalam Batavia Awal Abad 20: gedenkschriften van een oud-koloniaal (Jakarta: Komunitas Bambu, 2004). 
berdiri dengan gaya-gaya yang disukai para pria, dengan pandangan mata nakal ke arah kamera. Ada juga model yang menatap kamera dengan malu-malu atau takut-takut seolah-olah melihat senjata yang diarahkan pada dirinya.

Hal ini disetujui pula oleh Rob Nieuwenhuys (1998: 109-110) yang mengecam beberapa 'oknum' pemerintah kolonial yang menggunakan koleksi foto-foto telanjang itu dengan dalih rubrik volkstypen (tipe penduduk). Bahkan ada koleksi foto telanjang yang menggunakan judul 'Souvenir de voyage', hasil bidikan fotografer profesional.

Potret-potret separuh telanjang dan telanjang perempuan pribumi itulah yang justru laku dan menghasilkan banyak uang di Eropa. Sebagai contoh potret telanjang seorang gadis yang berusia empat belas tahun dengan pose yang menantang. Kaki kirinya diangkat bertumpu pada sebuah peti besi dengan teko keramik di sebelahnya. Pandangannya ke arah samping lensa. Sementara itu kainnya tergeletak di kaki kanan. Layar di belakangnya bergambar ala neo-klasik (Faber et al. 1988: 81). Jelas ada pengarah gaya yang mengatur pose perempuan pribumi itu sehingga dapat menghasilkan potret yang 'ekspresif'.

Potret perempuan pribumi separuh telanjang itu juga yang menjadi daya tarik pengunjung Prancis pada pameran Exposition Universelle di Paris pada tahun 1889. Saat itu pemerintah Belanda mengirimkan tontonan dalam bentuk tampilan Le village Javanais, sebuah kampung Jawa. Rasa penasaran dengan kartu pos dan potret dari Hindia, khususnya Jawa, yang bergambar penari Jawa yang separuh telanjang (hanya mengenakan kain sebatas dada) membuat para pengunjung begitu antusias ingin menyaksikan secara langsung penampilan para penari itu di depan umum. Hal itu tidak mengherankan karena 'ketelanjangan' di muka umum di masa itu merupakan hal yang luar biasa karena sebelumnya mereka hanya dapat melihat melalui lukisan dan kartu pos dari negeri Timur (Bloembergen 2004: 94).

Selama enam bulan pameran di Paris itu terhitung mampu menyedot 875.000 pengunjung. Komentar-komentar bermunculan setelah menyaksikan penampilan para penari dari Jawa yang separuh telanjang itu. Dituliskan bahwa para pengunjung 'jatuh cinta' pada penari-penari muda itu seperti Damina, Wakiem, Sariem, dan Soekia yang baru berusia dua belas hingga enam belas tahun. Bahkan Baudelaire, seorang penyair, mengungkapkan kekagumannya dengan menulis La Belle Wakiem (Wakiem yang cantik). Sajak ini pun sempat dimuat di Java Bode edisi 9 Agustus 1893 (Bloembergen 2004: 93).

Ada hal menarik sehubungan dengan 'ketelanjangan' tersebut. Pada tahun 1898 firma H. Bunning mengeluarkan seri kartu pos Yogyakarta, Prambanan, dan Borobudur. Salah satunya kartu pos bergambar patung Buddha di Borobudur. Kartu itu lalu dikirim ke Belanda sebagai kartu ucapan tahun baru. Ketika tiba di sana, petugas pos Rotterdam menganggap gambar Buddha yang telanjang 'kurang sopan' untuk disampaikan pada si penerima. Maka sang Buddha diberikan 'pakaian' dahulu, kartu pos itu dimasukkan dalam amplop. Si penerima terpaksa harus membayar biaya ekstra 7,5 sen (Haks dan Wachlin 2004: 20). 
Memasuki abad kedua puluh objek-objek potret dari objek individu bergeser ke alam. Kali ini potret pemandangan alam yang indah di HindiaBelanda menjadi objek yang disukai, seperti sungai, danau, sawah, alam pegunungan serta sesekali potret sebuah kampung pribumi beserta beberapa penduduk pribumi.

Cita-cita Pax Neerlandica yang didengungkan oleh Snouck Hurgronje, pada awal abad kedua puluh mulai memperlihatkan wujudnya ${ }^{6}$ Ditaklukkannya Aceh, Bali setelah sebelumnya Jawa, terutama di bawah pemerintahan Gubernur Jenderal Van Heutsz memperlihatkan bahwa Hindia-Belanda sudah siap untuk penanaman modal luar negeri. Daerah di luar Jawa pun mulai mendapat perhatian karena pada abad kesembilan belas Jawalah yang menjadi pusat kegiatan. Demikian pula kebijakan politik etis yang diperkenalkan pada tahun 1901 yang salah satu tujuannya meningkatkan kesejahteraan penduduk pribumi. ${ }^{7}$

Perubahan di bidang politik dan perekonomian ini juga mempengaruhi perkembangan fotografi di Hindia-Belanda. Dari para juru potret yang bekerja mandiri menjelma menjadi perusahaan besar yang bertujuan menghasilkan produk massa. Seperti perusahaan fotografi milik Onnes Kurkdjian (18511903), seorang Armenia, di Surabaya yang setelah kematiannya menjadi Naamloze Vennootschap (N.V.), semacam Perseroan Terbatas (P.T.). Pada tahun 1904 berubah menjadi N.V. Photograpische Atelier Kurkdjian Soerabaia dan sekitar tahun 1915 diambil alih oleh N.V. Farmaceutische Import-Maatschappij Helmig \& Co. Perusahaan-perusahaan fotografi penting lainnya yang didirikan pada masa ini adalah Charls \& Van Es \& Co. di Batavia dan Hisgen \& Co. di Semarang. Bahkan ada yang merupakan bagian dari sebuah perusahaan besar seperti Foto 'Lux' Garoet pimpinan Thilly Weissenborn yang merupakan bagian dari N.V. De Garoetsche Apotheek en Handelsonderneming. ${ }^{8}$

Pada masa ini para juru potret tidak lagi terbatas pada orang Eropa, orang Tionghoa dan Jepang pun juga mulai menjadi juru potret. Studio-studio milik mereka dapat ditemui di desa-desa dan kota-kota tempat masyarakat Tionghoa atau Jepang tinggal. Sementara itu, para juru potret dari kalangan pribumi hampir tidak ada, kecuali beberapa pribumi yang menganut agama nasrani atau yang sering berhubungan dengan orang Eropa. Yang termasuk kategori ini adalah Kassian Cephas (1845-1912) dan puteranya Sem Cephas (1870-1918),

Kehidupan di Hindia-Belanda pun semakin nyaman dan aman. Hal ini tentu mengundang orang Eropa lainnya untuk datang ke Hindia. Apabila pada masa sebelumnya yang datang berkunjung kebanyakan para petualang

$6 \quad$ Pax Neerlandica merupakan cita-cita Snouck Hurgronje untuk membentuk negara Belanda Raya yang meliputi negara Belanda di Eropa dan Hindia-Belanda di Asia Tenggara. Dua daerah yang berjauhan secara geografis ini diharapkan akan bergabung dalam satu ikatan. Lihat Suminto (1985: 14-15).

Lihat Locher-Scholten(1981).

8 Beberapa karya dari Thilly Weissenborn dibeli oleh Louis Couperus, seorang sastrawan Belanda untuk ilustrasi bukunya Oostwaarts (1924) yang merupakan kumpulan laporan perjalanan wisata di Hindia untuk Haagsche Post. Namun, sayang foto-foto tersebut hilang di perjalanan sewaktu dikirim dari Hindia ke Belanda. 
yang ingin mencicipi keeksotisan Hindia-Belanda, sekarang yang datang adalah para pejabat berpendidikan tinggi, pengusaha hingga para turis. Hal tersebut dapat dilihat dari foto-foto yang dibuat pada masa ini. Pembangunan daerah-daerah pemukiman baru yang nyaman bagi orang Eropa di kota-kota besar, sekolah-sekolah, rumah sakit-rumah sakit, hotel-hotel, jalur kereta, jalan raya serta aneka barang yang khusus didatangkan dari Eropa dan Amerika. Rumah, perabotan, makanan, cara berpakaian dengan kata lain cara hidup para tuan dan nyonya di Hindia semakin mirip dengan cara hidup di Eropa. Ini dikenal dengan istilah Eropanisasi. Bahkan, lucunya ada banyak keluarga pribumi yang mengadaptasi model dan mengikuti kebiasaan Eropa ini.

Seperti di masa sebelumnya, para juru potret ini tidak hanya mendapatkan pesanan dari perorangan. Mereka juga mendapat 'tugas negara' dari pemerintah atau perusahaan yang menginginkan mengabadikan ekspansi mereka secara ekonomi di Hindia-Belanda. Pemerintah atau perusahaan meminta para juru potret untuk mengambil gambar bangunan-bangunan yang dianggap merepresentasikan hal tersebut, seperti bank, pabrik, dan lembagalembaga pemerintah. Bahkan acara kunjungan Gubernur Jenderal atau peresmian sebuah perusahaan perkebunan baru juga menjadi momen yang dipilih. Foto-foto yang dihasilkan itu biasanya dimuat dalam gedenkalbum/ jubileumalbum (album peringatan) atau dijual secara lepas.

\section{FOTO UNTUK PROMOSI PARIWISATA}

Hal yang menarik, foto-foto hasil bidikan itu dimuat pula dalam brosur, kartu pos, majalah, buku-buku panduan wisata seperti Come to Java yang disebarkan ke seluruh negara yang dianggap memiliki potensi mendatangkan para turis dalam jumlah yang cukup banyak.

Penggunaan kartu pos, buku panduan wisata, dan brosur sebagai bahan promosi pariwisata merupakan awal dari suatu cara pandang populer pada masa itu. Buku panduan wisata tersebut sebagian besar diterbitkan oleh sebuah badan resmi pemerintah yang mengurusi promosi turisme di HindiaBelanda, Officieel Vereeniging Toeristenverkeer Bureau (sering disingkat VTV). Badan turisme ini didirikan pada tanggal 13 April 1908 di Batavia dengan besluit yang ditandatangani oleh Gubernur Jenderal Van Heutsz. ${ }^{9}$ Mulai saat itu Pemerintah Hindia-Belanda mengatur (atau memonopoli) ke mana saja para turis itu harus berkunjung dan objek apa saja yang harus dilihat. Oleh karena itu, mereka memerlukan foto-foto berkualitas yang dapat menunjang buku panduan wisata, brosur, dan kartu pos yang mereka terbitkan.

Sejarah kartu pos di Hindia-Belanda sendiri dimulai sekitar 100 tahun yang lalu ketika kartu pos bergambar pertama kali muncul. Sebuah artikel berjudul 'De Triumf der Briefkaarten' (Kemenangan kartu pos) di Bataviaasch Nieuwsblad edisi 6 Januari 1905 menceritakan sejarah singkat perkembangan kartu pos yang merupakan ide Dr. Heinrich von Stephan di Jerman pada tahun 1865. Meskipun akhirnya Dr. Emmanuel Hermann dari Akademi Militer WienerNeustadt yang diakui sebagai pencetusnya, Belanda sendiri 'mengadopsi'

\footnotetext{
9 Lihat kajian mengenai lembaga ini dalam Sunjayadi (2006).
} 
briefkaart (kartu pos) pada tahun 1871 yang segera disusul negeri jajahannya, Hindia-Belanda (Haks dan Wachlin 2004:15). Belanda 'mengadopsi' briefkaart tanpa gambar. Di bagian depan hanya tercetak tempat untuk alamat dan perangko sedangkan bagian belakang untuk menulis berita. Pada tahun 1893 muncul briefkaart bergambar pertama di Batavia (Bergambar Gedung Sositet Harmoni, Museum Bataviaasch Genootschap van Kunsten en Wetenschappen serta Istana Gubernur Jenderal di Batavia) yang kemudian disusul dengan prentbriefkaart (surat kartu bergambar).

Awalnya, pemerintah secara resmi tidak mengizinkan pihak swasta mencetak kartu pos bergambar, seperti untuk iklan bisnis atau dagang. Namun, akhirnya larangan itu dicabut secara resmi dan pihak swasta diizinkan mencetak kartu pos bergambar.

Bonnef dan Grant (1994: 56) menyebutkan beberapa percetakan besar yang memproduksi kartu pos ini, seperti G. Kolff di Batavia (74 gambar), Visser \& Co. di Batavia dan Bandung (55 gambar), Van Ingen di Surabaya (34 gambar), G.C.T van Dorp di Semarang (24 gambar). Selanjutnya, beberapa pengusaha seperti Alberti di Sabang (58 gambar), Liem Sioe Yaam di Fort de Kock-Bukit Tinggi (32 gambar) serta Tio Tek Hong di Batavia (72 gambar).

Kebanyakan gambar kartu pos merupakan hasil reproduksi foto. Foto-foto itu merupakan hasil kerja fotografer yang sudah dikenal, seperti dari firma Woodbury \& Page di Batavia, Chephas di Yogyakarta. Terkadang foto-foto yang dipergunakan untuk kartu pos merupakan gambar yang diambil pada abad kesembilan belas. Biasanya gambar yang diambil adalah kehidupan sehari-hari dalam suasana kemodernan Eropa di tempat nun jauh di sana. Serta keberhasilan yang telah mereka capai di negeri koloni, seperti gambar pabrik, pelabuhan, gedung kesenian yang disandingkan dengan 'keeksotisan' alam Hindia-Belanda, seperti gambar gunung berapi (Haks dan Wachlin 2004: 22).

Selain kartu pos lepas terdapat pula rangkaian seri kartu pos bergambar, seperti yang dikeluarkan oleh firma Masman \& Stroink di Semarang pada tahun 1905. Misalnya pada seri kelima yang dikenal dengan Mooi Insulinde (Hindia yang indah) memuat gambar Gunung Bromo dengan lautan padang pasirnya, pemandangan kota, dan 'rampokpartij' atau upacara rampokan di Jawa (Haks dan Wachlin 2004: 24).

Awal abad kedua puluh firma Tio Tek Hong di Pasar Baru, Weltevreden, menjadi percetakan kartu pos terkemuka. Kartu-kartu pos bergambar Batavia dan Buitenzorg dijual dengan harga bervariasi mulai 5 sen hingga 75 sen (Haks dan Wachlin 2004: 27). Pada waktu yang sama muncul gejolak kartu pos mania yang 'menyapu' dunia. Bataviaasch Nieuwsblad edisi 14 Januari 1901 menuliskan berdasarkan survei dari tanggal 9 hingga 16 Agustus 1900 tercatat 10.128.569 kartu pos bergambar diposkan hanya di Jerman. Surat kabar yang sama pada tanggal 7 November 1903 menulis bahwa pada tahun 1902 kirakira 900 juta helai kartu pos digunakan di seluruh dunia, tidak termasuk Asia dan Afrika (Haks dan Wachlin 2004: 27).

Pada tahun 30-an, pemerintah Hindia-Belanda telah menyeleksi sekitar 12.000 lembar foto yang disajikan dalam buku panduan wisata serta kartu 
pos yang dikirimkan ke 30 pusat turisme di seluruh dunia. ${ }^{10}$

Foto-foto yang ditampilkan seperti bangunan-bangunan, jalan raya, jembatan, jalur kereta, bendungan, kabel telegraf memperlihatkan HindiaBelanda yang sudah dimodernisasi. Foto-foto yang menampilkan modernisasi itu berdampingan dengan foto-foto pemandangan alam (aneka tanaman, sungai, lembah, pegunungan, pantai), binatang, atau reruntuhan candicandi di Jawa. Para penduduk pribumi yang ditampilkan dalam foto-foto itu kebanyakan ditampilkan dengan pakaian khas sebagai pembantu, penghibur/ seniman (penari, pemusik), penjual keliling, pengrajin atau sedang melakukan suatu upacara adat, berjudi, dan minum arak. ${ }^{11}$

Bila kita mengamati foto-foto tersebut akan tampak bahwa foto-foto tersebut berupaya memuaskan sebuah 'fantasi kolonial' yang merupakan fantasi Barat tentang otherness, tentang dunia pinggiran yang dipelihara oleh Barat. Serta sebuah pandangan bahwa semua itu adalah tempat-tempat 'tertutup' - murni secara etnis, tradisional secara budaya, tak terusik oleh modernitas (Hall 1992: 305). Walaupun dalam hal ini ada semacam ironi karena ada pula foto-foto yang menampilkan Hindia-Belanda yang telah dimodernisasi. Tujuannya sebenarnya tentu adalah meyakinkan para calon turis bahwa mereka akan mengunjungi Tropical Holland di Asia. HindiaBelanda yang telah ditaklukkan sehingga aman untuk dikunjungi.

Bonnef dan Grant (1994: 57-58) juga memperinci kurang lebih 1.000 koleksi kartu pos (tahun 1900-1930-an) mengenai Hindia-Belanda, kartu pos yang berlatar belakang Jawa (659 lembar), Sumatra (239 lembar), Bali, Sulawesi, Maluku, Kalimantan, Flores, dan Lombok (100 lembar).

Akhir tahun dua puluhan, ketika Jawa sudah dianggap tidak murni lagi karena sudah semakin modern ditambah lagi munculnya gerakan nasionalis yang semakin radikal, perhatian dialihkan ke Bali yang masih dianggap murni dan relatif lebih aman. Bali yang juga dikenal dengan sebutan pulau dewata dijadikan pilihan alternatif para turis. Vickers (1989: 11) menggambarkan bagaimana pemerintah kolonial Belanda mendefinisikan kembali citra Bali dari citranya sebagai sebuah tempat yang liar tak beradab menjadi citra sebuah pulau surga. Titik perhatian utama turisme yang sebelumnya adalah pemandangan alam di Jawa bergeser pada budaya di Bali. Foto-foto perempuan Bali yang bertelanjang dada juga menjadi daya tarik.

Ketenaran Bali inilah membuatnya dijadikan tema pada saat pameran kolonial internasional di Paris tahun 1931. Pemerintah Hindia-Belanda pun

$10 \quad$ Tourism in Netherlands-Indië Vol IX. No. 1, January-February 1934.

11 Lihat koleksi kartu pos Haks dan Wachlin (2004). Dalam buku itu dimuat lima ratus kartu pos yang dibagi dalam tujuh wilayah geografis. Mulai dari wilayah Barat hingga ke Timur. Dari Sumatra, Jawa, Bali dan Sunda Kecil, Borneo (Kalimantan), Celebes (Sulawesi), sampai ke Irian Jaya dan Kepulauan Maluku. Ada satu bagian khusus, yaitu Batavia (Jakarta) yang memang paling banyak menghasilkan kartu pos serta menghasilkan kartu pos yang paling indah. Tujuh bagian itu dibagi lagi dalam kategori: pemandangan kota, pemandangan alam (lanskap), arsitektur, kegiatan sehari-hari, dan tentu saja potret. Untuk buku panduan wisata lihat kajian menarik Iskandar P. Nugraha (2000) mengenai buku-buku panduan wisata dalam "Dutch politics of seeing: tourist guidebooks in colonial Indonesia", makalah tidak diterbitkan. 
tidak tanggung-tanggung mensponsori pameran ini. Untuk pintu masuk ke dalam paviliun Hindia-Belanda dibuatlah duplikat pintu masuk pura Camenggon di Sukawati, Bali Selatan, yang tingginya 50 meter lengkap dengan ukiran dari batu granit. Pembangunan duplikat pintu masuk pura itu menghabiskan waktu 40 hari. Tidak hanya itu, 50 penari ditambah pemain gamelan Bali didatangkan untuk ikut meramaikan pameran. Hasilnya, Pemerintah Hindia-Belanda kembali meraih kesuksesan. Berbondongbondong arus turis datang ke Bali (Bloembergen 2004: 181). ${ }^{12}$

\begin{tabular}{|l|r|r|r|r|r|r|r|r|r|r|}
\hline & 1926 & 1927 & 1928 & 1929 & 1930 & 1932 & 1933 & 1934 & 1935 & 1936 \\
\hline Belanda & 257 & 361 & 365 & 438 & 397 & 404 & 498 & 828 & 812 & 802 \\
\hline Amerika & 91 & 150 & 224 & 480 & 665 & 574 & 596 & 578 & 674 & 896 \\
\hline Inggris & 32 & 65 & 105 & 159 & 107 & 113 & 185 & 224 & 439 & 502 \\
\hline Australia & 17 & 17 & 51 & 80 & 107 & 79 & 178 & 96 & 231 & 321 \\
\hline Jerman & 25 & 40 & 63 & 94 & 103 & 103 & 97 & 90 & 51 & 89 \\
\hline Prancis & - & - & - & - & - & - & - & - & 117 & 91 \\
\hline Lain-lain & 23 & 47 & 119 & 177 & 179 & 162 & 241 & 323 & 216 & 179 \\
\hline Total & 445 & 680 & 927 & 1428 & 1555 & 1435 & 1795 & 2139 & 2540 & 2880 \\
\hline
\end{tabular}

Tabel 1. Jumlah turis yang mengunjungi Bali 1926-1936.

Sumber: Jaarverslag van Vereeniging Toeristenverkeer 1928-1929 (Batavia: Javasche Boekhandel en Drukkerij); Indisch Verslag 1931 ('s-Gravenhage: Landsdrukkerij); Indisch Verslag 1937 ('s-Gravenhage: Landsdrukkerij).

Pada pameran Het daghet in den Oosten pada bulan Juni 1941 di Amsterdam yang diselenggarakan oleh Het Koloniaal Instituut (sekarang Het Koninklijk Instituut voor de Tropen, Amsterdam), salah satunya menampilkan foto seorang perempuan Bali bertelanjang dada. Foto yang dibuat oleh J.C. Mol (1891-1954) ini dijual dengan dilengkapi teks: 'deze foto hielp mee om de Indische fototentoonstelling tot het succes te maken' (foto ini membantu pameran foto Hindia ini sukses). J.C. Mol adalah seorang direktur N.V. Multifilm Haarlem yang memiliki cabang di Batavia, pada tahun 1935 mendapatkan pesanan membuat foto-foto di Jawa dan Bali dari Rotterdamsche Lloyd.

\section{FOTO TURISME DAN BENIH NASIONALISME}

Yang mengejutkan adalah foto-foto yang dipergunakan untuk promosi turisme - yang sebelumnya dipakai dalam Gedenkboek (buku peringatan/ kenangan) atau Handbook (buku pegangan) buatan pemerintah kolonial - oleh VTV itu dijadikan ilustrasi bagi buku-buku pelajaran sekolah Belanda dan dipakai oleh para murid Indonesia.

Para murid tersebut termasuk kelompok yang disebut oleh Robert van Niel sebagai para neo-priyayi yang kelak menjadi founding fathers negeri ini. Mereka inilah yang kelak mengajarkan nasionalisme pada kita. ${ }^{13}$ Beberapa sekolah

12 Lihat Tabel 1 tentang jumlah turis yang masuk Bali, khususnya mulai tahun 1932.

13 Lihat kajian Van Niel 1984. 
yang dijalankan oleh para teosofis Belanda di masa kolonial merupakan contoh sekolah yang menggunakan bahan tersebut. ${ }^{14}$ Foto-foto yang dipergunakan tersebut sama dengan foto-foto yang dipakai dalam Handbook of the Netherlands East Indies yang merepresentasikan Hindia. ${ }^{15}$

Hal menarik lainnya adalah kumpulan gambar cat air yang menjadi ilustrasi buku pelajaran sekolah dasar tahun 1913-1940. Gambar-gambar itu dicetak oleh firma Wolters-Noordhoff serta disebarkan di Hindia-Belanda. Gambar-gambar dalam buku itu serupa dengan foto-foto yang dibuat oleh VTV. Misalnya gambar jembatan besi untuk jalur kereta yang melintasi lembah Priangan. ${ }^{16}$

Foto-foto yang menjadi ilustrasi tersebut secara tidak langsung mengajarkan kepada para murid pada masa itu bahwa ada wilayah lain beserta penduduknya yang sebenarnya merupakan bagian di mana mereka tinggal. Dengan kata lain mereka juga menyadari bahwa sebenarnya mereka bagian dari wilayah tersebut seperti ujar Benedict Anderson tentang komunitas yang terbayang (imagined community).

Pada tahun 50-an Bernard Vlekke yang menulis Nusantara, a history of Indonesia (1959), sejarah yang lengkap tentang Hindia-Belanda juga menggunakan foto-foto promosi turisme sebagai ilustrasi bukunya. Foto-foto ilustrasi itu juga kelak digunakan pemerintah Indonesia dalam buku 'babon' sejarah nasional Indonesia terbitan Balai Pustaka (Nugraha 2000: 18).

Tentunya pengaruh foto-foto turisme kolonial terhadap munculnya benih nasionalisme melalui para neo-priyayi di Indonesia memerlukan penelitian tersendiri yang lebih mendalam. Oleh karena itu, hal tersebut tidak dibahas di sini. Namun, ada hal yang dapat dicatat, yaitu foto-foto turisme itu mungkin dapat menjadi tonggak awal pembentukan citra kita terhadap keindahan yang sebenarnya bukan dibuat untuk kita. Serta dapat digunakan untuk membayangkan adanya wilayah atau penduduk di wilayah lain yang sebenarnya merupakan bagian dari kita.

Foto-foto tersebut selain dapat menjadi catatan sejarah yang dapat membantu imajinasi visual kita mengetahui situasi masa lalu, secara tidak langsung juga menjadi sarana 'menemukan' atau 'mengenal Indonesia'.

\section{PENUTUP}

Masuknya teknologi fotografi ke Hindia-Belanda ternyata mendukung promosi pariwisata kolonial di Hindia-Belanda. Foto-foto yang dihasilkan awalnya hanya dimanfaatkan oleh sekelompok orang tertentu (untuk tujuan pribadi) dengan maksud untuk kenang-kenangan akhirnya digunakan dalam bentuk kartu pos atau ilustrasi dalam buku panduan maupun majalah pariwisata (untuk tujuan umum).

Berbagai pilihan foto yang disajikan mencerminkan kepentingan pemerintah kolonial dalam menampilkan citra Hindia-Belanda sebagai

$14 \quad$ Lihat kajian menarik Iskandar P. Nugraha (1995) tentang penggunaaan bahan-bahan ini.

15 Lihat foto-foto untuk ilustrasi Handbook of the Netherlands East-Indies (Batavia: G. Kolff and Co, 1930).

16 Gambar-gambar tersebut dicetak kembali. Lihat Hella S. Haasse 2004. 
Tropical Holland (Belanda yang tropis). Suatu wilayah yang telah didomestikasi dan menawarkan kenyamanan sehingga aman untuk dikunjungi.

Penggunaan foto-foto dari masa kolonial tersebut secara tidak sadar juga turut mengabadikan estetika dalam jejak sejarah fotografi di Indonesia. Gambar-gambar yang ditampilkan membentuk citra kita sekarang tentang keindahan - citra yang sebenarnya disajikan bagi para turis masa kolonial dan bagaimana mengenal serta menjadi 'Indonesia'. Suatu proses yang hingga kini masih berlangsung entah sampai kapan.

\section{DAFTAR PUSTAKA}

Bloembergen, Marieke. 2004. Koloniale inspiratie. Leiden: KITLV Uitgeverij. Bonnef, Marcell dan Stephen Grant. 1994. “Bonser baiser de Batavia: Cartes postales des Indes Néerlandaises", Archipel 47: 53-85.

Brousson, H.C.C Clockener. 2004. Batavia awal abad 20: gedenkschriften van een oud-koloniaal. Diterjemahkan oleh Achmad Sunjayadi. Jakarta: Komunitas Bambu.

Couperus, Louis. 1992. Oostwaarts. Cetakan kedua. Amsterdam/Antwerpen: Veen. (Cetakan pertama 1924, 's-Gravenhage: Leopold).

Faber, Paul et al. (red.). 1988. Toekang potret: 100 jaar fotografie in NederlandsIndië 1839-1939. Amsterdam: Fragment.

Haks, Leo dan Steven Wachlin. 2004. Indonesia: 500 early postcards. Singapore: Archipelago Press.

Hall, Stuart. 1992. "The question of cultural identity", di dalam: Stuart Hall (red.), Modernity and its future, hlm. 305. Cambridge: Polity.

Haasse, Hella S. 2004. Bij de les: schoolplaten van Nederlands-Indië. Amsterdam: Contact.

Knaap, G.J. 1995. "Woordbury \& Page: Fotografen in Indonesia 1857-1908", brosur pameran foto Woodbury \& Page di Erasmus Huis Jakarta, 18 Januari - 24 Februari 1995.

Knaap, G.J. 1999. Cephas, Yogyakarta: photography in the service of the Sultan. Leiden: KITLV Press.

Locher-Scholten, Elisabeth Bodine. 1981. Ethiek in fragmenten. Utrecht: HES.

Nieuwenhuys, Rob. 1998. Baren en oudgasten: Tempo doeloe, een verzonken wereld: fotografische documenten uit het oude Indië 1870-1920. Amsterdam: Querido.

Nugraha, Iskandar P. 1995. "Theosophical education movement in colonial Indonesia (1900-1947)". Tesis M.A., University of New South Wales, Australia.

Nugraha, Iskandar P. 2000. "Dutch politics of seeing; Tourist guidebooks in colonial Indonesia". Makalah tidak diterbitkan.

Raffles, T.S. 1817. The history of Java. London: Murray. 2 jilid.

Scidmore, Eliza. R. 1984. Java: the garden of the East. Singapore/Oxford: Oxford University Press.

Spoor, Ronald. 1980. Alexander Cohen, uiterst links, journalistiek werk 1887-1896. Amsterdam: Engelbewaarder. 
Suminto, Husnul Aqib. 1985. Politik Islam Hindia Belanda: het kantoor voor Inlandsche zaken. Jakarta: LP3ES.

Sunjayadi, Achmad. 2006. "Perhimpunan Turisme Batavia (1908-1942): Awal Turisme Modern di Jawa”. Tesis S2, Program Pascasarjana Ilmu Sejarah, Universitas Indonesia.

Surjomihardjo, Abdurrahman; Hilman Adil; dan Adrian Bernard Lapian. 2002. Beberapa segi perkembangan sejarah pers di Indonesia. Jakarta: Kompas.

Termorshuizen, Gerard. 1993. In de binnenlanden van Java: vier negentiendeeeuwse reisverhalen. Leiden: KITLV Uitgeverij.

Termorshuizen, Gerard. 2001. Journalisten en heethoofden; een geschiedenis van de Indisch-Nederlandse dagbladpers, 1744-1905. Leiden: KITLV Uitgeverij.

Tourism. 1934. Tourism in Netherlands India Vol. IX/1 (Januari-Februari)

Van Goor, J. 2000. Indische avonturen: opmerkelijke ontmoetingen met een andere wereld. Den Haag: Sdu.

Van Niel, Robert. 1984. Munculnya elit modern Indonesia. Diterjemahkan oleh Zahara Deliar Noer, disunting oleh Bur Rasuanto. Jakarta: Pustaka Jaya. (Seri Pustaka Sarjana No. 6; Judul asli The emergence of the modern Indonesian elite, KITLV Press, 1960).

Vickers, Adrian. 1989. Bali, a paradise created. Ringwood: Penguin.

Vlekke, Bernardus Hubertus Maria. 1959. Nusantara: a history of Indonesia. The Hague: Van Hoeve.

Wachlin, Steven. 1994. Woodbury \& Page: photographers Java. Leiden: KITLV Press.

\section{SUMBER RESMI TERCETAK}

Indische Staatsblad 1821 No. 6

Indische Staatsblad 1872 No. 38

Indische Staatsblad 1881 No. 226, 1890

Indische Verslag 1931 (s' Gravenhage: Landsdrukkerij)

Indische Verslag 1937 (s' Gravenhage: Landsdrukkerij)

Jaarverslag van Vereeniging Toeristenverkeer 1928-1929 (Batavia: Javasche Boekhandel en Drukkerij)

Koninklijk Besluit 1871 No. 1 